\title{
NUMBER AND MORPHOLOGY OF TILLER AGE GROUPS DURING SUMMER IN MARANDU PALISADEGRASS PASTURES PREVIOUSLY USED UNDER DEFERRED GRAZING
}

\author{
NÚMERO E MORFOLOGIA DE FAIXAS ETÁRIAS DE PERFILHOS DURANTE O \\ VERÃO EM PASTOS DE CAPIM-MARANDU PREVIAMENTE UTILIZADOS SOB \\ PASTEJO DIFERIDO
}

\author{
Manoel Eduardo Rozalino SANTOS ${ }^{1^{*}}$; Bruno Humberto Rezende CARVALHO ${ }^{1}$; \\ Angélica Nunes de CARVALHO ${ }^{1}$; Gabriel de Oliveira ROCHA ${ }^{1}$; \\ Flávia de Oliveira Scarpino VAN CLEEF ${ }^{2}$; Gustavo Jordan da Silva QUEIROZ; \\ Lucas Santos de MORAES ${ }^{1}$; Larissa Lais Santos do CARMO ${ }^{1}$ \\ 1. Universidade Federal de Uberlândia, Campus Glória, Faculdade de Medicina Veterinária, Uberlândia, MG, Brasil. \\ manoel.rozalino@ufu.br*; 2. University of Florida, Agronomy Department, Marianna, EUA.
}

\begin{abstract}
The relative contribution of young, mature and old tillers in the canopy influences the production and structure of the pasture. The objective with this work was to evaluate the balance between tiller appearance and tiller death (BAL) during spring and early summer, the morphology and percentages of young, mature and old tillers in Brachiaria brizantha cv. Marandu (marandu palisadegrass) with three conditions in late winter: short $(24.1 \mathrm{~cm})$, tall $(49.0 \mathrm{~cm})$ and tall $(50.0 \mathrm{~cm}) /$ mown $(8 \mathrm{~cm})$. Tall and tall/mown pastures presented higher BAL in September and October, respectively. In January, BAL was higher in short and tall/mown pastures than in tall pasture. The tiller number was higher in short pasture, intermediate in tall/mown pasture and lower in tall pasture. The percentage of old tillers was higher in short and tall pastures compared to tall/mown pasture. The percentage of live leaf lamina reduced, while the percentage of dead leaf lamina increased with tiller age. Mowing of the tall marandu palisadegrass pasture in late winter increases the renewal of tillers in the spring and decreases the percentage of old tillers in the summer. The old tillers present worse morphology than young tillers.
\end{abstract}

KEYWORDS: Brachiaria brizantha syn. Urochloa brizantha. Morphological composition. Mowing. Sward height. Tillering dynamics

\section{INTRODUCTION}

The Brachiaria brizantha syn. Urochloa brizantha cv. Marandu (marandu palisadegrass) is one of the most used forage grasses for pasture in Brazil. The marandu palisadegrass presents a great flexibility in grazing management and, during the autumn and winter of the Southeast and CentreWest regions of Brazil, it can be used under deferred grazing (EUCLIDES et al., 2007; SILVA et al., 2016).

Deferred grazing is a relatively simple strategy of management, which has the potential to produce pasture for the winter season (VILELA et al., 2012; SILVA et al., 2016) when the tropical forage production is generally decreased by adverse conditions. After using the deferred pasture at the end of winter, the height and the forage mass can vary, depending on the management previously adopted in the deferment period.

The structure of the deferred pasture in late winter may influence the renewal pattern of the tiller population during subsequent seasons. It is expected that pastures kept at low heights at the end of winter present more intense and early tillering during spring (SANTOS et al., 2011; SANTANA et al., 2014). This is due to the greater light incidence at the base of the plants, which stimulates the development of basal buds on tillers (SOUSA et al., 2013). Conversely, in taller pastures, the high selfshading at the base of the canopy can inhibit tillering (MATTHEW et al., 2000) and consequently, delay regrowth during spring.

In this context, mowing the taller pastures allows elimination of the great forage mass coming from winter, but its effects on tillering still need to be better understood. Thus, mowing eliminates the apical meristem of the old tillers, which may stimulate the appearance of young tillers (SOUZA et al., 2015). However, this positive effect may be counterbalanced by the greater shading at the base of the plants, caused by the large amount of forage mass that remains in the area. 
Variations of appearance and mortality of tillers during spring and summer, caused by the structure of late winter grasses, can alter the relative participation of tillers of different ages in the pasture. This has relevant consequences because young tillers have greater growth rates (MONTAGNER et al., 2011; BARBOSA et al., 2012), better structural characteristics (SANTOS et al., 2018) and nutritional value (SANTOS et al., 2006) and also, are more responsive to growth factors (PAIVA et al., 2011), when compared to old tillers.

This study was developed with the objectives of: (1) knowing how the sward height and pasture mowing in late winter modify the tillers' renewal in spring and summer; (2) determining the relative participation of the tiller age groups in the pasture during early summer; and (3) comparing the morphology of young, mature and old tillers of Brachiaria brizantha cv. Marandu during the early summer.

\section{MATERIAL AND METHODS}

This study was carried out from January 2014 to February 2015, at the experimental Farm Capim-branco, at the Federal University of
Uberlândia, in Uberlândia, MG, Brazil. The approximate geographical coordinates of the site are $18^{\circ} 53^{\prime} 19^{\prime \prime}$ south latitude and $48^{\circ} 20^{\prime} 57^{\prime \prime}$ longitude west, and its altitude is $835 \mathrm{~m}$. The experimental area consisted of a pasture with Brachiaria brizantha cv. Marandu (marandu palisadegrass), without signs of degradation, subdivided into nine paddocks (experimental units) of $800 \mathrm{~m}^{2}$ each, in addition to a reserve area totalling 1.5 hectares.

The soil of the experimental area was classified as dystrophic dark red latosol with a clay texture. In January of 2014, soil samples were taken for analysis of the fertility level and the results were: $\mathrm{pH}$ in $\mathrm{H}_{2} \mathrm{O}$ : 6.0; $\mathrm{P}$ : 6.3 (Mehlich-1) and $\mathrm{K}$ : $153.0 \mathrm{mg} \mathrm{dm}{ }^{-3} ; \mathrm{Ca}^{+2}: 5.0 ; \mathrm{Mg}^{2+}: 2.0$ e $\mathrm{Al}^{3+}: 0.0$ $\mathrm{cmol}_{\mathrm{c}} \mathrm{dm}^{-3}\left(\mathrm{KCl} 1 \mathrm{~mol} \mathrm{~L}^{-1}\right)$; sum of bases: $7.4 \mathrm{cmol}_{\mathrm{c}}$ $\mathrm{dm}^{-3}$; effective cation exchange capacity (CTC): 7.4 $\mathrm{cmol}_{\mathrm{c}} \mathrm{dm}^{-3}$; total CTC: $11.0 \mathrm{cmol}_{\mathrm{c}} \mathrm{dm}^{-3}$; base saturation: $69.0 \%$. Based on these results, $50 \mathrm{~kg} \mathrm{ha}^{-1}$ of $\mathrm{P}_{2} \mathrm{O}_{5}$ and $\mathrm{N}$ were applied in January of 2014, in addition to another dose of $50 \mathrm{~kg} \mathrm{ha}{ }^{-1}$ of $\mathrm{N}$ on 03/03/2014.

The climate of the region is Aw type, tropical savannah with dry winter season (ALVARES et al., 2013). Climatic conditions were monitored at a meteorological station located about $100 \mathrm{~m}$ from the experimental area (Figure 1).

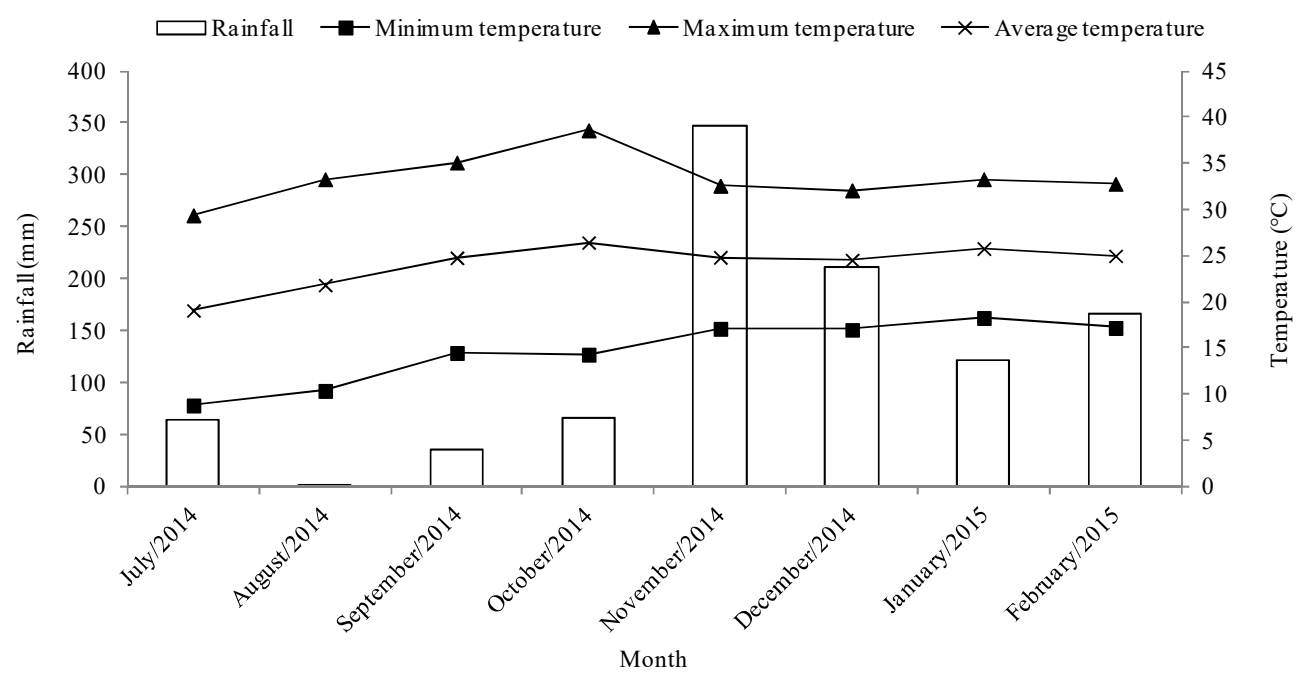

Figure 1. Accumulated rainfall, and minimum, average and maximum daily temperatures from July 2014 to March 2015.

The mean temperature and monthly precipitation were used to calculate soil water balance (THORNTHWAITE; MATHER, 1955), considering soil water storage capacity of $40 \mathrm{~mm}$ (Figure 2). 


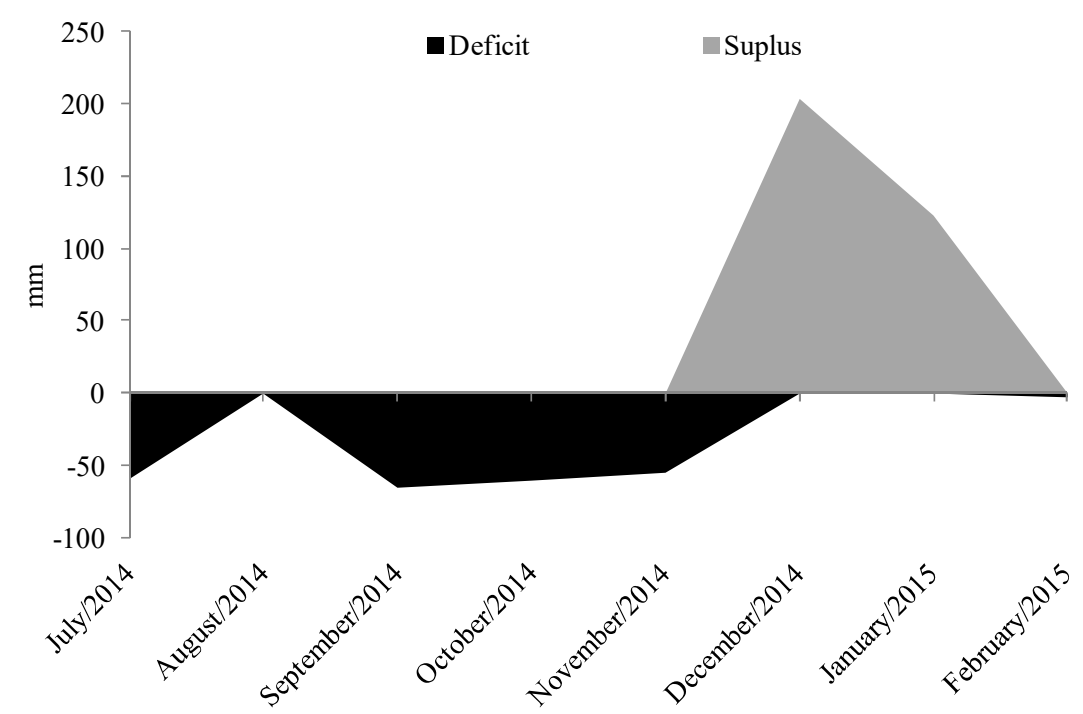

Figure 2. Water soil balance of the experimental area from July 2014 to February 2015.

The experiment was conducted in a completely randomised design with three replicates. The paddocks were the experimental units. Three conditions of deferred pastures in late winter were evaluated: short, tall and tall/mown pastures. From spring on, the balance between tiller appearance and death were evaluated with repeated measures in time from September 2014 to January 2015. In addition, the morphological characteristics of young, mature and old tillers were also compared in each pasture condition, and a subdivided plot scheme was used, in which the pasture conditions corresponded the plots and the age groups of tillers to subplots.

From January to March 2014, all pastures were managed with continuous stocking with sheep and a variable stocking rate to maintain pastures at three medium heights $(15,35$ and $45 \mathrm{~cm})$. Each height was implemented in three paddocks. For this, the heights were measured weekly with a ruler, at 30 random points per paddock, considering the distance from the soil surface to the highest live leaves of the pasture. The put-and-take technique (MOTT; LUCAS, 1952) was used to adjust the stocking rate to maintain the desired sward height, using lambs of $30 \mathrm{~kg}$ body weight.

All pastures were deferred for 92 days, from $03 / 17 / 2014$ to $06 / 17 / 2014$. After this period, the use of all pastures began from 06/17/2014 until $09 / 07 / 2014$, which were managed with continuous stocking by sheep. The allocation of the animals in the paddocks was done systematically to maintain the same initial stocking rate of three sheep/paddock, which corresponded, on average, to 4.0 animal units (AU) ha ${ }^{-1}$. One AU corresponded to $450 \mathrm{~kg}$ body weight.
At the end of the grazing period, on $07 / 09 / 2014$, pastures deferred at $15 \mathrm{~cm}$ were low (24.1 $\mathrm{cm}$ and $2,420 \mathrm{~kg} \mathrm{ha}^{-1}$ of dry matter(DM)); and those deferred at $35 \mathrm{~cm}$ presented a height $(49 \mathrm{~cm})$ and forage mass $\left(3,837 \mathrm{~kg} \mathrm{ha}^{-1}\right.$ of DM) similar to those deferred at $45 \mathrm{~cm}\left(50 \mathrm{~cm}\right.$ and $4,211 \mathrm{~kg} \mathrm{ha}^{-1}$ $\mathrm{DM})$. In this case, in order to cause differences between both conditions, pastures deferred at $45 \mathrm{~cm}$ were mowed to $8 \mathrm{~cm}$ on $09 / 17 / 2014$. Therefore, it was possible to obtain three pasture conditions at the end of winter (short, tall and tall/mown pastures), which were evaluated.

After this period, all pastures remained without animals for 75 days, until the new tillers from spring regrowth reached $30 \mathrm{~cm}$ of height, when the grazing period started, lasting until $02 / 20 / 2015$. During the grazing period, all pastures were managed at a $30 \mathrm{~cm}$ average height, with continuous stocking and a variable stocking rate, using sheep of $30 \mathrm{~kg}$ body weight, which had unrestricted access to mineral salt. The pasture height control was performed weekly and on average, its value was $34 \mathrm{~cm}$.

The tillering dynamics were evaluated in three representative areas of $0.07 \mathrm{~m}^{2}$ each per experimental unit. At the beginning of the evaluation, these areas contained plants with the same average sward height. The areas were demarcated using a PVC ring of $30 \mathrm{~cm}$ diameter, which was fixed to the ground by wire clips. All the tillers within the ring were counted and marked first on $9 / 4 / 2014$ and from there the new tillers were counted again and marked every 30 days with flat wire coated plastic of different colours to identify each generation until 02/02/2015. Posteriorly, the balance between tiller appearance and death of 
Number and morphology...

tillers was calculated by subtracting these variables (SBRISSIA et al., 2010). In addition, it was possible to identify and quantify the total number of tillers, as well as to classify them into three age groups (young, mature and old). The young tillers corresponded to those of less than two months of age; mature ones were two to four months of age; and the older ones were older than four months (PAIVA et al., 2011).

At the end of the experiment, all young, mature and old tillers were identified and cut at ground level. Posteriorly, the tillers were quantified and separated into live leaf, live stem and dead leaf blade. These morphological components were oven dried at $65{ }^{\circ} \mathrm{C}$ for 72 hours and then weighed. Prior to drying, the live leaf blades had two small portions of their ends cut (apex and base), so that an approximately rectangular leaf segment was obtained. The width and length of each segment were measured and by the product of these dimensions, the leaf area of the leaf segments was obtained. These were placed in a forced ventilation oven at $65^{\circ} \mathrm{C}$ for 72 hours and then weighed. Then, the specific leaf area $\left(\mathrm{cm}^{2}\right.$ of leaf blade $\mathrm{g}^{-1}$ of leaf blade) was calculated. The leaf area of each category of tiller was calculated by the product of its specific leaf area by its live leaf mass of each tiller category.

Data concerning the balance between tiller appearance and death tiller were analysed statistically using the analysis of variance in a completely randomised design with three
SANTOS, M. E. R. et al.

repetitions, using the PROC MIXED of SAS ${ }^{\circledR}$ (Statistical Analysis System). The covariance matrices were chosen using the Akaike criterion (WOLFINGER, 1993). The pasture condition and the month of grazing and their interaction were considered as fixed effects. The months of the grazing period were considered measures repeated over time. The other variable responses were analysed using the GLM procedure of SAS. Treatment means were estimated using the 'LSMEANS' command. When appropriate, the means were compared by the Student-NewmanKeuls' test $(\mathrm{P}<0.05)$.

\section{RESULTS}

The balance between appearance and tiller mortality rates (BAL) was influenced by the interaction between pasture conditions in late winter and the months of the year (Table 1). The BAL of short and tall/mown pastures was greater during October and lower during September, compared to the other months of the year. On the tall pasture, the BAL was greater not only in October, but also in September, with a reduction in subsequent months, specifically in January, the only month in which the BAL was negative. Tall and tall/mown pastures presented greater BAL in September and October, respectively. In November and December, the BAL did not vary among the pasture conditions. However, in January, BAL was greater in short and tall/mown pastures than in the tall pasture (Table 1).

Table 1. Balance between appearance and mortality of tiller (\% in 30 days) in spring and summer according to the condition of marandu palisadegrass pastures at the late winter and after its use under deferred grazing.

\begin{tabular}{lcccc}
\hline \multirow{2}{*}{ Month } & \multicolumn{3}{c}{ Pasture condition at the late winter } & SEM \\
\cline { 2 - 5 } & Short & Tall & Tall/mown & \\
\hline September & $-0.3 \mathrm{bC}$ & $13.0 \mathrm{aA}$ & $-41.5 \mathrm{cD}$ & 16.4 \\
October & $33.0 \mathrm{bA}$ & $11.9 \mathrm{cA}$ & $77.1 \mathrm{aA}$ & 19.2 \\
November & $2.7 \mathrm{aB}$ & $1.6 \mathrm{aB}$ & $0.1 \mathrm{cC}$ & 0.8 \\
December & $4.3 \mathrm{aB}$ & $5.0 \mathrm{aB}$ & $6.5 \mathrm{aB}$ & 0.6 \\
January & $6.0 \mathrm{aB}$ & $-6.0 \mathrm{bC}$ & $12.2 \mathrm{aB}$ & 5.3 \\
\hline
\end{tabular}

SEM: standard error of the mean; For each characteristic, averages followed by the same letter, upper case in the column and lowercase in the row, do not differ by the Student Newman Keuls test $(\mathrm{P}>0.05)$.

The total population density was greater in the short pasture, intermediate in the tall/mown pasture and lower in the tall pasture (Table 2). The percentages of young and old tillers were greater in the short and tall pastures when compared to the tall/mown pasture, which was contrary to that observed for the percentage of mature tillers (Table 2). 
Table 2. Population density of total tillers and percentages of young, mature and old tillers in early February 2015 , according to the condition of the marandu palisadegrass pastures at the late winter and after its use under deferred grazing.

\begin{tabular}{lcccc}
\hline \multirow{2}{*}{ Variable } & \multicolumn{3}{c}{ Pasture condition at the late of winter } & \multirow{2}{*}{ SEM } \\
\cline { 2 - 4 } & Short & Tall & Tall/mown & \\
\hline Total tiller $\left(\mathrm{n}^{\circ} \mathrm{m}^{-2}\right)$ & $1,050 \mathrm{a}$ & $608 \mathrm{c}$ & $727 \mathrm{~b}$ & 132.0 \\
Young tiller $(\%)$ & $35.0 \mathrm{a}$ & $37.9 \mathrm{a}$ & $28.0 \mathrm{~b}$ & 2.9 \\
Mature tiller $(\%)$ & $34.0 \mathrm{~b}$ & $29.6 \mathrm{~b}$ & $56.0 \mathrm{a}$ & 8.2 \\
Old tiller $(\%)$ & $31.0 \mathrm{a}$ & $32.5 \mathrm{a}$ & $16.0 \mathrm{~b}$ & 5.3 \\
\hline
\end{tabular}

SEM: standard error of the mean; For each characteristic, averages followed by the same letter do not differ by the Student Newman Keuls test $(\mathrm{P}>0.05)$.

Among the evaluated morphological characteristics, only the tiller weight was not influenced by the interaction between the pasture conditions and tiller age. Tiller weight was greater in the tall/mown pasture than in the others, and also increased with tiller age (Figure 3).
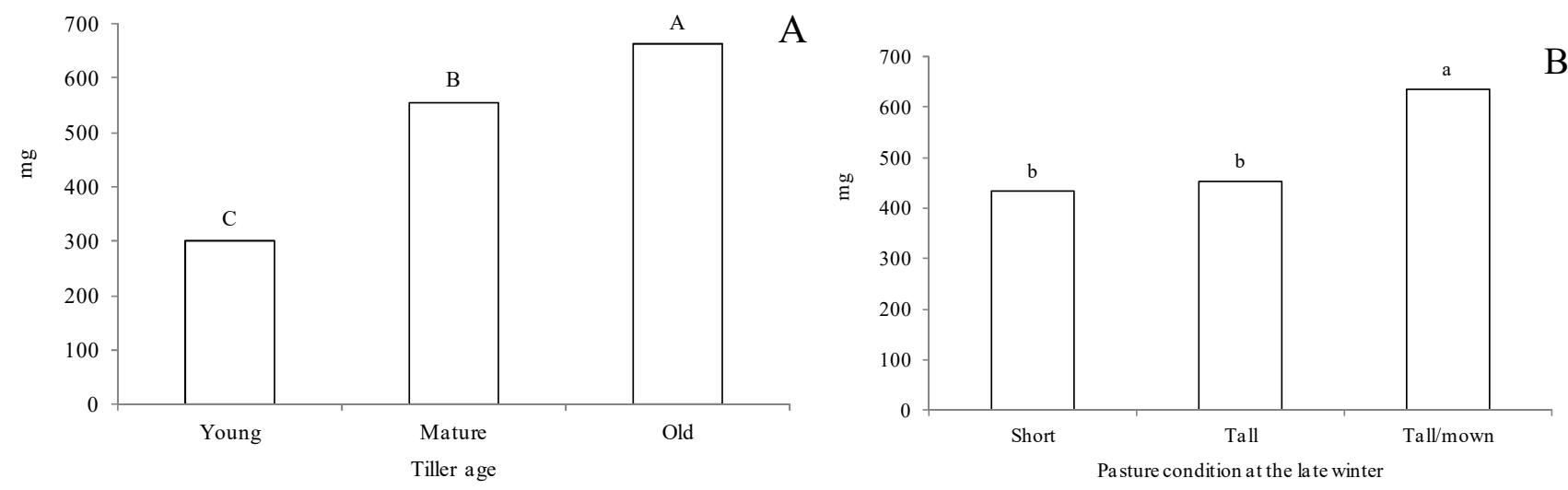

Figure 3. Weight of tiller with different ages (A) in early summer according to the condition of the marandu palisadegrass pastures in late winter (B); averages followed by the same letter don't differ by the Student Newman Keuls test $(\mathrm{P}>0.05)$.

The percentage of live leaf lamina (PLL) decreased with tiller age. The young tillers of the short pasture presented great PLL in comparison to the others. However, mature and old tillers of tall/mown pasture had greater PLL than short and tall pastures (Table 3 ).

The live stem percentage (LSP) of the young tillers was lower in the short pasture when compared to the others. The LSP of the mature tillers was lower in the tall/mown pasture than the tall pasture, while the LSP of the old tillers was lower in the tall/mown pasture than the others (Table 3). The percentage of dead leaf lamina (DLL) increased with tiller age. On the young and mature tillers, the DLL did not vary among grazing conditions. However, in the case of the old tillers, the DLL was lower in the tall/mown pasture, in comparison to the short and tall pastures (Table 3).

In the tall/mown pasture, the area of leaf lamina (ALL) did not vary among the ages of the tillers. However, in the short pasture, the ALL was greater in the young tillers than in the other age classes. Otherwise, in the tall pasture, the ALL of young and mature tillers was greater than the old tillers. The ALL of all age groups of tillers was greater in the tall/mown pasture in comparison to the short and tall pastures (Table 3). 
Table 3. Morphological characteristics of age groups of tillers in early summer according to the condition of the marandu palisadegrass pastures in late winter and after its use under deferred grazing.

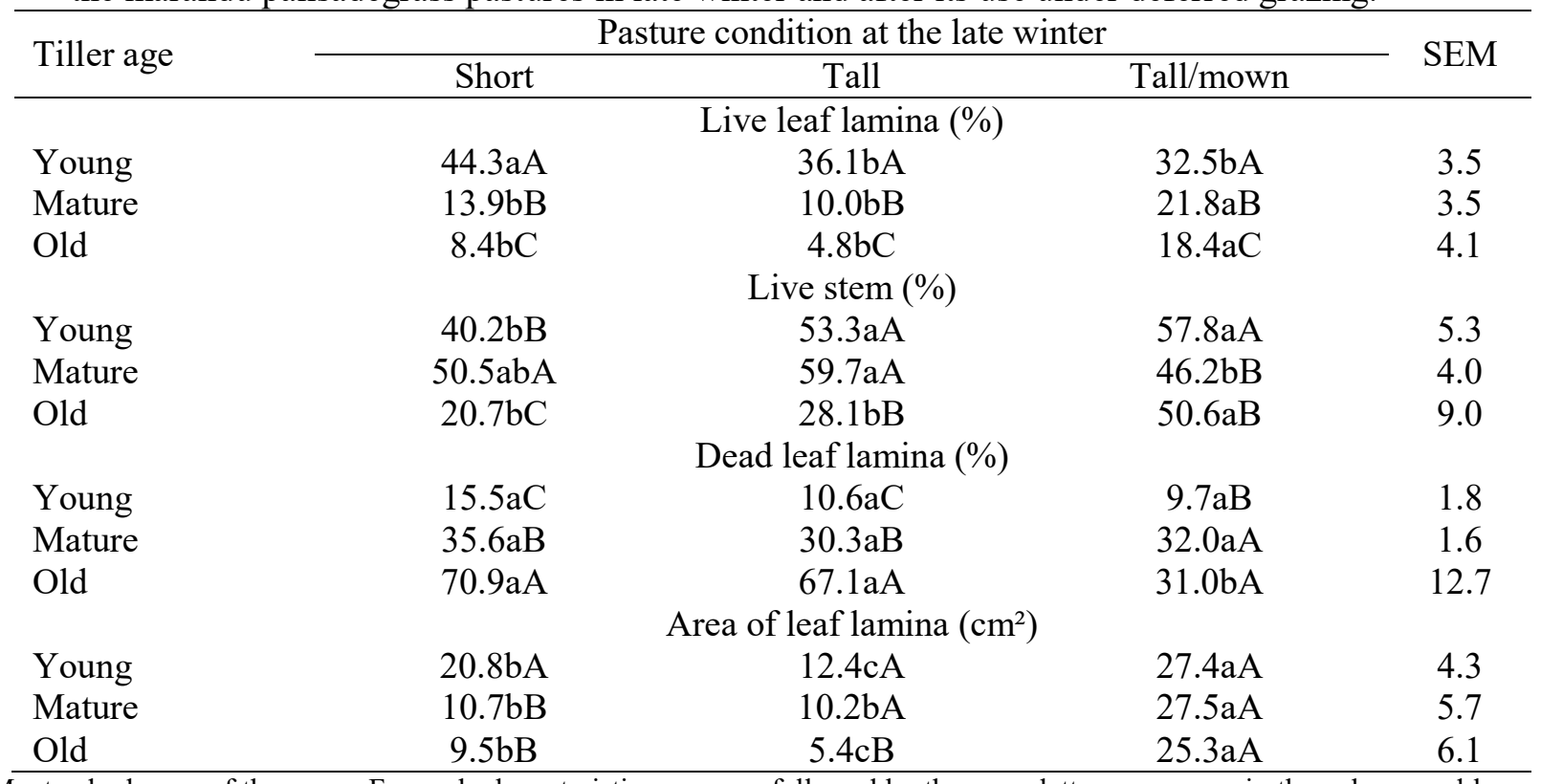

SEM: standard error of the mean; For each characteristic, averages followed by the same letter, uppercase in the column and lowercase in the row, do not differ by the Student Newman Keuls test $(\mathrm{P}>0.05)$.

\section{DISCUSSION}

In the tall/mown pasture, greater tiller death occurred in September due to the high elimination of the apical meristem of the tillers. This led to the balance between tiller appearance and tiller death (BAL) being negative and lower in September on tall/mown pasture, when compared to the short and tall pastures (Table 1). However, in October, the BAL of tall/mown pasture was greater than the other pastures (Table 1) due to its greater tillering. Due to the elimination of the apical meristems of the tillers, the process of apical dominance is lost and consequently, there is a stimulus to tillering (MATTHEW et al., 2000). This tillering may have been favoured considering the possibility of the tall pasture having a high stock of reserve compounds at the end of winter. In winter, pasture growth is typically reduced (CALVANO et al., 2011; SANTOS et al., 2013) and under these conditions, the plant uses very little of its organic reserves (DA SILVA et al., 2014; FERRO et al., 2015). Thus, these organic reserves may have been used more intensely in early spring, after mowing, to ensure high tillering of tall/mown pasture, which may justify the greater BAL in comparison to the other pasture conditions (Table 1). However, this hypothesis still needs to be investigated in future works.

In all pastures, from October to January, there was a decrease in BAL (Table 1). Probably, the greater tillering in October due to the improvement of climatic conditions, such as increase of rainfall (Figure 1) and absence of water deficit in the soil (Figure 2), increased the population density of tillers in the canopies. Consequently, the pastures may have increased their leaf area index and in effect, increased the shading of basal buds, which inhibits tillering (MATTHEW et al., 2000; DA SILVA et al., 2015). This lower tillering may have been the cause of the BAL decrease from October to January (Table 1).

At the end of the experiment (February 2015), the tiller population density was greater in the short pasture than in the tall and tall/mown pastures (Table 2). Probably, the short pasture presented a greater number of tillers during the whole period of evaluation, as in this condition, more light focuses on the base of the plants, stimulating the buds to develop in basal tillers (CALVANO et al., 2011). On the other hand, in the tall pastures, the greater shading inside the canopy in early spring may have inhibited tillering, which would justify the lower number of tillers in February 2015 (Table 2).

The similar tiller population density between tall and tall/mown pastures (Table 2) indicates that mowing did not reduce the number of tillers in the summer (February). As already discussed, mowing may have initially caused high tiller mortality (negative BAL in September, according to Table 1). However, in the following month, high tillering occurred (high BAL in October, according to Table 1), which caused the 
number of tillers to increase and remain high until February.

The greater BAL in October of the tall/mown pasture allows inference that this pasture condition showed a more rapid renewal of the tiller population in comparison to the other pasture condition. Thus, it is likely that these pastures presented younger tillers more commonly in early spring, which had their development during the late spring and summer. Thus, in February, tall/mown pastures showed greater percentages of mature tillers and lower percentages of young tillers, a pattern of response contrary to that observed in short and tall pastures (Table 2).

The young tillers presented structural characteristics more adequate for animal consumption and performance, since this tiller category had a greater percentage of live leaf lamina, as well as a lower percentage of dead leaf lamina (Table 3), which is contrary to the verified patters for old tillers. In working with the marandu palisadegrass, Paiva et al. (2012) also observed that young tillers showed a larger number of live leaves, but a lower number of senescing leaves than older tillers. Therefore, these authors concluded that tiller age is an important factor interfering with structural characteristics and may influence plant and animal responses in pastures by altering sward structure.

The young tillers also had a greater area of leaf lamina than the old tillers in short and tall pastures (Table 3). This result indicates that the young tillers may contribute to the increment of the leaf area index (LAI) of the pastures, since its population density is not low in the forage canopy. The LAI is important for the interception of solar radiation by pasture (PERI et al., 2003), a premise for the photosynthesis of the canopy.

In the tall/mown pasture, the negative BAL in September indicates that there was high tiller mortality in this month. Then, the high BAL in October (Table 1) shows that intense tillering occurred in this pasture. The large number of young tillers that emerged from October in the tall/mown pasture developed themselves in months of a favourable climate for plant growth (Figures 1 and 2 ). Thus, all ages of tiller presented greater weight and area of leaf lamina in tall/mown pasture, when compared to short and tall pastures (Table 3 ). This factor may also have caused a greater lengthening of the stem of the young tillers and, therefore, may justify the greater percentage of live stems of young tillers, in relation to the mature and old ones in the tall/mown pastures (Table 3).

In the low pasture and mainly in the tall pasture, the renewal of the tiller population was probably later, so that the appearance of young tillers may have been more time consuming. Thus, young and mature tillers had a shorter development time until February, when tiller characterisation was performed and thus, presented lower weight and leaf area in relation to these same tiller classes of tall/mown pasture (Table 3). In addition, in low and tall pastures, many tillers that appeared before spring may have taken longer to die and, in effect constituted the population of old tillers in the canopy. These old tillers may have had lower growth rates because they developed under unfavourable weather conditions typical of winter, as Montagner et al. (2011) observed in a study on the morphogenic and structural characteristics of tillers of different ages of guinea grass cv. Mombaca. As a consequence, it is natural for older tillers to have a lower weight and area of leaf lamina in short and tall pastures than in tall/mown pasture (Table 3). These factors may also have been responsible for the lower growth of the stem of the old tillers compared to the young and mature ones in the short and tall pastures (Table 3).

In the tall/mown pasture, the structural characteristics of the old tillers were more favourable to animal consumption compared to the old tillers present in the short and in the tall pastures (Table 3).

It is noteworthy that the structural characteristics of old tillers are generally worse compared to those of young and mature tillers, as observed by Barbosa et al. (2012) with guinea grass cv. Tanzania and Santos et al. (2018) with marandu palisadegrass.

The results of this study evidence that the condition of the pasture in late winter has pronounced effects on the population dynamics and structural characteristics of the tillers in subsequent seasons. In this context, the evaluation of grazing management strategies should take place over time in order to understand the nature and magnitude of the residual effects of the management practices adopted in a specific season of the year.

\section{CONCLUSIONS}

Mowing tall pasture of marandu palisadegrass in late winter promotes early population renewal of tillers during spring, less relative participation of old tillers during the summer and improves the structure of the mature and old tillers during the summer.

The young tillers present better structural characteristics than the old tillers. 


\section{ACKNOWLEDGEMENTS}

The authors would like to thank the Fundação de Amparo à Pesquisa do Estado de Minas Gerais, the Conselho Nacional de Desenvolvimento Científico e Tecnológico (CNPq) and the Fundação de Apoio Universitário (FAU) for funding. This study was financed in part by the Coordenação de Aperfeiçoamento de Pessoal de Nível Superior - Brasil (CAPES) - Finance Code 001 .

RESUMO: A contribuição relativa de perfilhos jovens, maduros e velhos no dossel influencia a produção e a estrutura do pasto. O objetivo com o trabalho foi avaliar durante a primavera e o início do verão o balanço entre aparecimento e mortalidade de perfilho (BAL), a morfologia e as percentagens de perfilhos jovens, maduros e velhos nos pastos de Brachiaria brizantha cv. Marandu (capim-marandu) com três condições ao fim do inverno: baixo $(24,1 \mathrm{~cm})$, alto $(49,0 \mathrm{~cm})$ e alto $(50,0 \mathrm{~cm}) /$ roçado $(8 \mathrm{~cm})$. Os pastos alto e alto/roçado apresentaram maior BAL em Setembro e Outubro, respectivamente. Em Janeiro, o BAL foi maior nos pastos baixo e alto/roçado do que no pasto alto. O número de perfilho foi maior no pasto baixo, intermediário no pasto alto/roçado e menor no pasto alto. As percentagens de perfilhos jovens e velhos foram maiores nos pastos baixo e alto, em comparação ao pasto alto/roçado. A percentagem de lâmina foliar viva reduziu, enquanto que a percentagem de lâmina foliar morta aumentou com a idade do perfilho. A roçada do pasto alto de capimmarandu no fim do inverno aumenta a renovação de perfilho na primavera e diminui a percentagem de perfilho velho no pasto no verão. O perfilho velho apresenta pior morfologia do que o perfilho jovem.

PALAVRAS-CHAVE: Altura do pasto. Brachiaria brizantha syn. Urochloa brizantha. Composição morfológica. Perfilhamento. Roçada.

\section{REFERENCES}

ALVARES, C. A.; STAPE, J. L.; SENTELHAS, P. C; GONÇALVES, J. L. M.; SPAROVEK, G. Köppen's climate classification map for Brazil. Meteorologische Zeitschrift, v. 22, n. 6, p. 711-728, 2013. https://doi.org/10.1127/0941-2948/2013/0507

BARBOSA, R. A.; NASCIMENTO JUNIOR, D.; VILELA, H. H.; SOUSA, B. M. L.; SILVA, S. C.; EUCLIDES, V. P. B.; SILVEIRA, M. C. T. Morphogenetic and structural characteristics of guinea grass tillers at different ages under intermittent stocking. Revista Brasileira de Zootecnia, v. 41, p. 1583-1588, 2012. https://doi.org/10.1590/S1516-35982012000700005

CALVANO, M. P. C. A.; EUCLIDES, V. P. B.; MONTAGNER, D. B.; LEMPP, B.; DIFANTE, G. S.; FLORES, R. S.; GALBEIRO, S. Tillering and forage accumulation in Marandu grass under different grazing intensities. Revista Ceres, v. 58, p. 781-789, 2011. https://doi.org/10.1590/S0034-737X2011000600015

DA SILVA, S. C.; PEREIRA, L. E. T.; SBRISSIA, A. F.; HERNANDEZ-GARAY, A. Carbon and nitrogen reserves in marandu palisade grass subjected to intensities of continuous stocking management. Journal of Agricultural Science, v. 1, p. 1-15, 2014. https://doi.org/10.1017/S0021859614001130

DA SILVA, S.; SBRISSIA, A. F.; PEREIRA, L. E. T. Ecophysiology of $\mathrm{C}_{4}$ forage grasses - understanding plant growth for optimising their use and management. Agriculture, v. 5, n. 3, p. 598-625, 2015. http://www.mdpi.com/2077-0472/5/3/598/htm https://doi.org/10.3390/agriculture5030598

EUCLIDES, V. P. B.; FLORES, R. S.; MEDEIROS, R. N.; OLIVEIRA, M. P. Diferimento de pastos de braquiária cultivares Basilisk e Marandu, na região do Cerrado. Pesquisa Agropecuária Brasileira, v. 42, p. 273-280, 2007. https://doi.org/10.1590/S0100-204X2007000200017

FERRO, M. M.; ZANINE, A. M.; FERREIRA, D. J.; SOUZA, A. L.; VALÉRIO GERON, L. J. Organic reserves in tropical grasses under grazing. American Journal of Plant Sciences, v. 06, p. 2329-2338, 2015. https://doi.org/10.4236/ajps.2015.614236 
MATTHEW, C.; ASSUERO, S. G.; BLACK, C. K.; SACKVILLE HAMILTON, N. R. Tiller dynamics of grazed swards. In: LEMAIRE, G.; HODGSON, J.; MORAES, A.; NABINGER, C.; CARVALHO, P. C. R. Grassland ecophysiology and grazing ecology. Wallingford: CAB International, 127-150, 2000. https://doi.org/10.1079/9780851994529.0127

MONTAGNER, D. B.; NASCIMENTO JR, D. D; SOUSA, B. M. L.; VILELA, H. H.; EUCLIDES, V. P. B.; SILVA, S. C.; SBRISSIA, A. F.; CARLOTO, M. N. Morphogenetic and structural characteristics of tillers of guinea grass of different age and grazing severities. Revista Brasileira de Zootecnia, v. 40, p. 2105-2110, 2011. https://doi.org/10.1590/S1516-35982011001000006

MOTT, G.O.; LUCAS, H.L. The designs conduct, and interpretation of grazing trials on cultivated and improved pastures. In: INTERNATIONAL GRASSLAND CONGRESS, State College, Proceedings State College, Pennsylvania, p. 1380-1385, 1952.

PAIVA, A. J.; DA SILVA, S. C.; PEREIRA, L. E. T.; MESQUITA, P.; GUARDA, V. D. Morphogenesis on age categories of tillers in marandu palisadegrass. Scientia Agricola, v. 68, p. 626-631, 2011.

https://doi.org/10.1590/S0103-90162011000600003

PAIVA, A. J.; SILVA, S. C.; PEREIRA, L. E. T.; GUARDA, V. D. A.; PEREIRA, P. M.; CAMINHA, F. O. Structural characteristics of tiller age categories of continuously stocked marandu palisade grass swards fertilized with nitrogen. Revista Brasileira de Zootecnia, v. 41, n. 1, p. 24-29, 2012. https://doi.org/10.1590/S1516-35982012000100004

PERI, P. L.; MOOT, D. J.; MCNEIL, D. L.; LUCAS, R. J. 2003. Modelling net photosynthetic rate of fieldgrown cocksfoot leaves to account for regrowth duration. New Zealand Journal of Agricultural Research, v. 46, p. 105-115, 2003. https://doi.org/10.1080/00288233.2003.9513536

SANTANA, S. S.; FONSECA, D. M.; SANTOS, M. E. R.; SOUSA, B. M. L.; GOMES, V. M.; NASCIMENTO JR., D. Initial height of pasture deferred and utilized in winter and tillering dynamics of signal grass during the following spring. Acta Scientiarum, v. 36, p. 17-23, 2014.

https://doi.org/10.4025/actascianimsci.v36i1.20463

SANTOS, P. M.; CORSI, M.; PEDREIRA, C. G. S. Tiller cohort development and digestibilidade in Tanzania guinea grass (Panicum maximum cv Tanzania) under three levels of grazing intensity. Tropical Grasslands, v. 40, p. 84-93, 2006.

SANTOS, M. E. R.; GOMES, V. M.; FONSECA, D. M.; ALBINO, R. L.; SILVA, S. P.; SANTOS, A. L. Número de perfilhos do capim-braquiária em regime de lotação contínua. Acta Scientiarum, v. 33, n. 1, p. 1-7, 2011. https://doi.org/10.4025/actascianimsci.v33i1.10440

SANTOS, M. E. R.; SILVEIRA, M. C. T.; GOMES, V. M.; FONSECA, D. M.; SOUSA, B. M. L.; SANTOS, A. D. Pasture height at the beginning of deferment as a determinant of signal grass structure and potential selectivity by cattle. Acta Scientiarum, v. 35, p. 379-385, 2013.

https://doi.org/10.4025/actascianimsci.v35i4.20421

SANTOS, M. E. R.; AVILA, A. B.; CARVALHO, A. N.; ROCHA, G. O.; CLEEF, F. S. V.; SEGATTO, B. N.; VASCONCELOS, K. A.; PEREIRA, R. S. Marandu palisadegrass management strategies at the beginning of the deferment period and effects on tillering. Semina: Ciências Agrárias, v. 39, n. 4, p. 16617-1626, 2018. http://dx.doi.org/10.5433/1679-0359.2018v39n4p1617

SBRISSIA, A. F.; SILVA, S. C.; SARMENTO, D. O. L.; MOLAN, L. K.; ANDRADE, F. M. E.; GONCALVES, A. C.; LUPINACCI, A. V. Tillering dynamics in palisadegrass swards continuously stocked by cattle. Plant Ecology, v.206, p. 349-359, 2010. https://doi.org/10.1007/s11258-009-9647-7 
SILVA, G. M.; SILVA, F. F.; VIANA, P. T.; RODRIGUES, E. S. O.; MOREIRA, C. N.; MENESES, M. A.; ABREU JR., J. S.; RUFINO, C. A.; BARRETO, L. S. Avaliação de forrageiras tropicais: Revisão. Publicações em Medicina Veterinária e Zootecnia (PUBVET), v.10, n.3, p.190-196, 2016.

https://doi.org/10.22256/pubvet.v10n3.190-196

SOUSA, B. M. L.; SANTOS, M. E. R.; VILELA, H. H.; SILVEIRA, M. C. T.; ROCHA, G. O.; FREITAS, C. A. S.; SILVA, N. A. M.; NASCIMENTO JR., D. Piata palisade grass deferred with two distinct initial heights: luminous environment and tillering dynamics. Revista Brasileira de Zootecnia, v. 42, p. 36-43, 2013.

https://doi.org/10.1590/S1516-35982013000100006

SOUZA, D. O. C.; FERNANDES, W. B.; SILVA, G. F.; SANTOS, M. E. R.; SILVA, S. P. A roçada do capimmarandu alto no fim do inverno melhora a estrutura do pasto no início do verão. Enciclopédia Biosfera, v. 11, n. 21, p. 12-22, 2015.http://dx.doi.org/10.18677/Enciclopedia_Biosfera_2015_069

THORNTHWAITE, C. W.; MATHER, J. R. The water balance. Centerton, NJ: Drexel Institute of Technology - Laboratory of Climatology, 1955. 104p. (Publications in Climatology, vol. VIII, n.1). (NÃO HÁ CITAÇÃO NO TEXTO).

VILELA, H. H.; SOUSA, B. M. L.; SANTOS, M. E. R.; SANTOS, A. L.; ASSIS, C. Z.; ROCHA, G. O.; FARIA, B. D.; NASCIMENTO JR., D. Forage mass and structure of piata grass deferred at different heights and variable periods. Revista Brasileira de Zootecnia, v. 41, p. 1625-1631, 2012.

https://doi.org/10.1590/S1516-35982012000700010

WOLFINGER, R. Covariance structure selection in general mixed models. Communications in Statistics Simulation, v.22, n.4, p.1079-1106, 1993. https://doi.org/10.1080/03610919308813143 